\title{
Secularisation, secularism, and the Thai state
}

\author{
Tomas Larsson ${ }^{1}$
}

Forthcoming in Routledge Handbook of Contemporary Thailand, edited by Pavin Chachavalpongpun, (Oxon: Routledge)

\section{Introduction}

Debates about secularisation (a historical process) and secularism (an ideology) have played a prominent role in social science debates. In the scholarship of the 1960s and 1970s, it was assumed that secularisation was a precondition for political modernity as well as an historical inevitability. Scholars today have abandoned both these preconceptions in favour of the view that there are multiple viable modernities and that religion is not going away. While much of the scholarship on secularisation and secularism remains centred on European and North American (and therefore Christian) experiences, more recent contributions have explored the politics of secularity "beyond the West," including in Southeast Asia (Six 2018). It is in this spirit that this chapter uses the concepts of secularisation and secularism to illuminate religion-state relations in Thailand.

Secularisation can refer to several distinct processes. Here attention will be focused on secularisation as it relates to the state. A central aspect of this is what Smith $(1974,4)$ referred to as polity secularisation: "the process by which a traditional system undergoes radical differentiation, resulting in separation of the polity from religious structures, substitution of religious modes of legitimation, and extension of the polity's jurisdiction into areas formerly regulated by religion." Secularism, in turn, is an ideology that

\footnotetext{
${ }^{1}$ The research leading to these results and their publication has received funding from the European Union's Horizon 2020 research and innovation programme under grant agreement $\mathrm{N}^{\circ} 770562$.
} 
seeks to justify "the separation of religious and political authority, the expulsion of religious law from the legal system, and sometimes even the exclusion of religion from the public sphere" (Künkler and Shankar 2018, 3).

It must be recognized, however, that secularism as state practice rarely results in a clean separation of religion and politics or church and state. On the contrary, some have argued that the modern secular state is characterized less by its separation from than its expanded role in managing "religion" (Asad 2003). According to this line of argument, secularism as political practice should be understood as the modern state's assertion of "sovereign power to reorganize substantive features of religious life, stipulating what religion is or ought to be, assigning its proper content, and disseminating concomitant subjectivities, ethical frameworks, and quotidian practices" (Mahmood 2015, 3). While scholars may disagree on how secularisation and secularism should be understood in relation to the state, they recognize that the politics of secularisation and secularism pivots around struggles that seek to define, to blur, or to deny the very existence of boundaries separating a "religious" domain from that which stands outside it ("the secular"). Gorski $(2018,49)$ helpfully highlights how such boundary struggles typically involve efforts to change either the location of activities from one domain to the other, or the degree of permeability between the religious and secular domains.

In light of these conceptual clarifications, Thailand is an ambiguous and contradictory case. It is possible to find evidence of secularisation processes leading to a significant degree of differentiation and separation of religion and state. However, the overarching ideological framework within which a "secular" Thai state has emerged in the course of the 19th and 20th centuries reflects a fundamentally "Buddhist" worldview. Thailand, in short, has adopted a predominant mode of secularism that translates into extensive state control of the religious field. 
Before proceeding, it should of course be noted that secularisation may be understood in less state-centric ways: as a decline in popular religiosity, as observed in many parts of Europe, or as the privatisation of religion, causing religion to cease being a public concern (Casanova 1994, 19-20). I set aside the question of religious decline because of a lack of detailed sociological data on religious beliefs and behaviour in Thailand. What we do know is that most Thais are "religious," and that the vast majority — close to 94 percent, according to the 2010 national census - identify as Buddhist. Only a minuscule proportion of the country's population ( 0.07 percent) claim they have "no religion" (National Statistical Office). In one recent survey, 56.6 percent responded that religion plays a "very important" role in their lives, and 31.1 percent responded that it plays a "rather important" role (World Values Survey). As this evidence suggests, economic and social modernisation has not triggered a decline of religious belief, practice, and identity in Thailand. For similar reasons I also set aside the question of secularisation as "privatisation" of religion. The growing popularity of meditation among laypersons otherwise provides a striking example of how a religious practice traditionally reserved for Buddhist monks has been privatized and disconnected from its roots in the Theravada Buddhist institutional and cultural context (Schedneck 2015).

\section{Thai conceptions of religion and secularity}

So far I have treated the categories of "religion" and "secular" as rather unproblematic. As recent scholarship has emphasized, they are anything but (Asad 2003). Defining what is and is not "religion" is a fraught scholarly endeavor, as well as a matter subject to intense political and legal contestation. This is true even in the most secular of states, where constitutional guarantees of religious freedom compel legislatures and courts to specify what counts as "religion" and as such deserves protection.

Analytically, religion can be defined as "a complex of prescribed practices that are based on premises about the existence and nature of superhuman powers" (Smith 2017, 3). Thai Buddhism, broadly conceived, is characterized by an impressive ability to incorporate within its scope an abundance of such 
superhuman powers - including but not limited to the impersonal powers of thamma and kam and a diverse and ever-expanding collection of deities, spirits, and ghosts. ${ }^{2}$ However, the country's religious and political authorities do not necessarily recognize practices relating to the latter as "religious," often viewing them, instead, as deplorable "superstitions" that distract from the pursuit of enlightenment (White 2003). The Thai term for "religion" is satsana. While originally referring to the teachings of Gautama Buddha, its use as a generic term that applies also to Hinduism, Christianity, Islam, etc., have deep historical roots (Thongchai 2015, 88).

As far as I am aware, a Thai conceptual history of the secular has yet to be written. Today, the most common way of expressing the idea of secularity is by reference to kharawat, denoting "householders," i.e. laypersons, as distinct from ordained monks (bhikkhu). The dichotomy between monastic and nonmonastic is therefore central to abstractions such as the idea of a secular state (rat kharawat, or lay state), secularism (kharawatniyom, lay-ism), and secularisation (kanplian pen kharawat, to make lay). In Thai academic debates another neologism, lokwisay (world-character), is sometimes also used in reference to secularity, but it is more rarely found in popular discourse. The term kharawat remains closely associated with its traditional referent: the devout lay supporter of the Buddhist sangha; it does not connote someone or something separated from "religion." Suraphot $(2017,151)$ has noted that Thai terms such as kharawat and lokwisai fail to capture the meaning of "secular" in Western philosophical thought. That may be correct but does not adequately recognize the ambiguity and complexity of the concept of the secular also in the West.

Rather than relying on these neologisms, Thai discourse about the relationship between religion and the state still tends to rely on a traditional Buddhist idiom. Theravada Buddhist polities have long emphasized

\footnotetext{
${ }^{2}$ Thamma (Thai) refers to universal law and to Buddha's teachings; it may also be spelled dharma (Pali) or dhamma (Sanskrit). Kam (Thai) refers to intentional action which affects the cycle of rebirth; it may also be spelled kamma (Pali) or karma (Sanskrit).
} 
the distinction between a "religious" sphere (satsanachak) and a "worldly" sphere (anachak). These represent two aspects of power, the two "wheels" of thamma. In sociological and legal terms satsanachak refers to the Buddhist monastic order that is governed by ecclesiastic laws laid down by the Buddha (vinaya). Anachak, in turn, refers to Buddhist kings and the secular (i.e., non-monastic) and universal law of the thammasat as well as king-made law (Reynolds 1994, 435-436). While the spheres are distinct, they also overlap, with the worldly sphere ultimately subsumed within the religious sphere. This can be seen not least in the fact that worldly rulers are expected to govern in accordance with Buddhist morality. The Jataka stories, which have greatly influenced the Thai political imagination, place emphasis on the importance of the ten royal virtues (thotsaphit ratchatham), moral ideals constraining "proper" Buddhist rulers (Jory 2017). It would therefore be wrong to think that anachak corresponds to the secular, if we by that mean something that stands "outside" religion. In fact, the thammaracha (righteous Buddhist ruler) is expected to govern in accordance with thamma, i.e., to administer "worldly" affairs in appropriate ways and to act as guarantor for the good governance of the Buddhist monastic order and the preservation of Buddha's teachings. Adopting a strategy that can be categorized as neotraditionalist (Laliberté 2013), the modern Thai state has continued to shoulder that ancient responsibility of Buddhist kingship (P. A. Payutto 1994).

Arguably, the Thai conception of anachak is somewhat analogous with pre-modern European conceptualizations of the secular and secularisation. These were theological concepts, grounded in a distinction between two kinds of clergy, religious (withdrawn from "the world") and secular (living in "the world"). "Secularisation" thus referred first to clergy and later to assets, functions, etc., leaving monasteries and entering "the world." However, while "the secular" may have denoted that which is outside the monastery walls, it did not, in medieval Christendom, in any way stand in contrast to or opposed to "religion," given that the surrounding society and the state were equally Christian. In the hitherto dominant Thai religiopolitical imaginary, likewise, satsanachak and anachak are two separate but equally Buddhist domains. 


\section{Religion and state formation}

In the earliest states in the territory that corresponds to contemporary Thailand, Buddhism and Brahmanism served important legitimating roles, exalting the head of state as (some combination of) a chakraphattirat (a Buddhist universal monarch), thewaracha (god-king), and thammaracha (righteous ruler), and by associating king-made law with the revealed universal legal principles of the thammasat (Baker and Pasuk 2016). The cosmological treatise Traiphum phraruang ("Three worlds according to King Ruang"), which dates back to the 1340s, served as a central ideological pillar of Thai kingship into the $19^{\text {th }}$ century, when its worldview was increasingly challenged by the arrival of a rival epistemology, Western in origin and scientific in character (Reynolds \& Reynolds 1982, Keyes 1989, Thongchai 2015).

The 19th-century encounter with the West, not least in the shape of Christian missionaries, served as catalyst for both religious and political reforms, with implications for the role of religion within the kingdom. Thai Buddhism and the Thai state were both subjected to "rationalizing" reforms led by kings Mongkut, Chulalongkorn, and Vajiravudh, and in the process Buddhism was turned into a pillar of both the Thai state and of official Thai nationalism (von der Mehden 1974). As a consequence of these developments, Buddhism shifted from being a matter of belief and ritual to being a component of an ethno-religious nationalist ideology in which an abstracted Buddhist identity was an essential marker of "Thainess" (khwam pen thai).

The modernisation of the Thai state in the late 19th and early 20th centuries required a radical transformation of the Thai legal system, separating law from its religious moorings (Engel 1975, Harding 2008). In contemporary Thailand, therefore, religion does not serve as a source of secular law. The main exception relates to Islam. A 1901 law decreed that Muslim minorities in the four Southern provinces should (in accordance with then prevailing custom) be governed by Islamic family law and Islamic courts 
(Loos 2006, 92). Although the government of Phibun Songkhram made an attempt to abolish Islamic law and courts, this caused such discontent that Bangkok in 1946 reinstated Islamic family law and Islamic courts for the southern provinces (Loos 2006, 94).

Rather than Buddhism serving as a source of secular law, secular lawmakers have occasionally aspired to fill perceived gaps in the vinaya. Most notably, canonical Buddhism provides no basis for structures that facilitate centralized governance and administration of the sangha. In Thailand this supposed lacuna has been remedied by a series of Sangha Acts, the first of which was enacted in 1902. These have established a nationally integrated hierarchical sangha administration, and regulated its relationship with the secular (i.e., non-monastic) bureaucracy. The Sangha Acts have sought to shape the sangha's governance structures in ways that closely mirror those of the secular bureaucracy. The 2018 Sangha Act significantly increased the Thai king's discretionary power over ecclesiastic affairs and appointments "in accordance with ancient royal traditions."

While it was absolute monarchs who fused sangha, state, and nation, subsequent political changes have not threatened the trinity. In 1932 a small group of bureaucrats, mostly French-trained, toppled the absolute monarchy and replaced it with a constitutional monarchy. Sovereignty was now transferred, at least in theory, to the people. However, the revolutionaries faced no opposition from the sangha, and they accordingly could see no compelling reason to overturn the well-established, symbiotic pattern of sanghastate relations. All post-1932 governments have continued to act as patrons and protectors of Buddhism, and exploited opportunities to instrumentalize religion for the purpose of state building. In the early 1930s, for instance, the government asked the monkhood to participate in elaborate rituals and propaganda campaigns intended to legitimize and, indeed, sacralize the new political order (Puli 2018). In the early 1940s, a hyper-nationalist government sought to impose a greater degree of religious uniformity on the population, and, especially, on the state bureaucracy. Because religious identity was regarded as a test of loyalty to the state, Christian and Muslim civil servants were forced to "return" to Buddhism in 
order to keep their jobs (Strate 2011, 75-76). During the Cold War, military governments mobilized the sangha in the struggle against communism, with clandestine US support. Clergy suspected of secretly harbouring radical sympathies were purged from the sangha, while other monks, and especially those belonging to the elite Thammayut sect, joined state-led Buddhist missionary and local development efforts intended to inoculate the impoverished peasantry in the country's north and northeast against communism (Ford 2017).

Since the mid-1970s, Thai state elites have intensified the public cultivation of a form of hyper-royalism with distinctly "religious" overtones. The royalist cult has been centered on king Bhumibol Adulyadet (r. 1946-2016) and articulated in terms of barami (Buddhist royal virtue). As a consequence, the Thai royal family has effectively been turned into "sacred beings and royalism [into] a religion" (Thongchai 2016, 9; see also Gray 1986, Stengs 2009, and Jackson 2010). Thai police and courts protect the image of the thammaracha by enforcing astonishingly harsh laws that treat signs of royal disrespect as blasphemous and heretical crimes that undermine the cultural foundations of the Buddhist-monarchical state (Streckfuss 2010). This illustrates how, in the dominant political imagination, satsanachak and anachak are understood as separate domains that are equally infused with Buddhist sacrality.

The introduction of the principle of modern constitutionalism should of course be understood as a move away from religious modes of political legitimation towards a political order where legitimacy rests on principles of citizenship and public participation. However, the modernisation of the Thai polity has been led by political elites who have, for the most part, been keen to ensure that the legal and political order remains an extensively Buddhicized one. This can most readily be discerned by noting the frequency with which tham/thamma serves as the etymological root for the neologisms of modern Thai statecraft: constitution (ratthathammanun), rule of law (nittitham), and good governance (thammaphiban)(Mérieau 2018). It is therefore virtually impossible to discuss (in Thai) the governance of the modern Thai state without invoking pre-modern conceptions of Buddhist moral order. In a similar manner, Thai state elites 
have gone to great lengths to infuse nominally secular public-policy frameworks with religious and specifically thammic meaning (Funahashi, 2016).

The Buddhicisation of the Thai constitutional order is also reflected in the legal position of the monarch. While there have been very many constitutions since the first one was introduced in 1932, they have all emphasized that the monarch is a Buddhist and acts as the "supreme defender" of religion in the realm (Ishii 1986, 38). While Thailand therefore is obliged to have a Buddhist head of state, Thai constitutions have never explicitly declared Buddhism the official state religion -- despite increasingly strident demands that it be recognized as such. While still falling short in that regard, the 2017 constitution nevertheless places an unprecedentedly heavy burden of responsibility on the Thai state with regards to the management of religion in general and Buddhism in particular. It decrees as follows:

"The state shall patronize and protect Buddhism and other religions. With a view to patronizing and protecting the Buddhism that has long been professed by the majority of the Thai people, the state shall promote and support education in and propagation of the principles of Theravada Buddhism for the purpose of mental and intellectual development, and must establish measures and mechanisms to prevent the desecration of Buddhism in any form. The state shall also encourage the participation of all Buddhists in the application of such measures and mechanisms."3

This section of the constitution empowers well-established mechanisms for extensive, and increasingly intrusive, bureaucratic control of Thai religiosity. Apart from the state-backed Buddhist ecclesiastical hierarchy, the National Office of Buddhism, the Ministry of Culture's Religious Affairs Department, and two state-funded Buddhist universities today play important roles in controlling and promoting religious activities (Larsson 2018a). Over the past few decades, furthermore, Thai governments have devoted a

\footnotetext{
${ }^{3}$ Section 67 of the 2017 Constitution of the Kingdom of Thailand. Author's translation from Thai.
} 
rapidly increasing share of their budgets to this religious bureaucracy (Larsson 2018b). In this context it is important to acknowledge that Thai state agencies seek to manage not only Buddhism, but also, but generally with a much lighter touch, the officially recognized minority religions (Christianity, Islam, Hinduism, and Sikhism). In addition, a separate arm of the state, the Ministry of Interior, administers religious cults and latthi (doctrines) that are not recognized as belonging to the category of satsana. Chinese temples and religious associations provide a prominent example of such non-satsana religiosity (Kataoka 2012).

Thus, the secular Thai state is for a host of constitutional, legal, and administrative reasons obliged to stipulate what counts as "religion" and to define what is and is not "Theravada Buddhism." It is furthermore obligated to ensure that the population embraces religious ethics, holds "correct" religious beliefs, and engages in "proper" religious practices. There are, perhaps unsurprisingly, serious doubts about the capacity of the Thai state to actually deliver on many of these fronts (Larsson 2016b, 2018a).

\section{Boundary struggles}

Boundary struggles are, as mentioned earlier, central features of the politics of secularisation and secularism. Here two issue areas — education and political citizenship — will serve as brief illustrations of how the boundary between the religious and the secular has been constructed and negotiated. Education provides a paradigmatic example of how two institutionally differentiated spheres - the religious and the secular - emerged in Thailand. The denial of full political citizenship to religious persons, in contrast, is a classic case of the state regulating the degree of permeability between religious and political domains. Adopting the Thai conceptual scheme, these are struggles over the location of activities in the realm of satsanachak or anachak, and over the ease with which activities and persons are allowed to move between these realms. 


\section{Education}

In pre-modern Siamese society, educational functions were located in temples, with monks serving as teachers in religious as well as more worldly realms of knowledge (such as medicine) (Ladwig 2011, 200). Once ruling kings embraced policies seeking to modernize the Thai education system around the turn of the 20th century, this gradually changed. Because of limited state capacities, the blow of secularisation was, however, softened. The new public schools were often located on temple grounds, and monks continued to play a prominent role in the education of children. However, as educational ambitions grew, political dissatisfaction with the limited ability of monks to provide instruction in modern scientific subjects caused the state to marginalize monks and to rely, increasingly, on public school teachers who had earned qualifications from the state's secular (non-monastic) teacher-training programmes.

In parallel with its takeover of public education, the Thai state simultaneously seized firmer control over much of what counts as religious education. King Chulalongkorn, notably, established two Buddhist universities in Bangkok, one each for the two most prominent Buddhist sects (Thammayut and Mahanikai), introduced a new national curriculum and monastic examination system, and developed a system of royal honours and ecclesiastic promotions designed to incentivize monks to take Buddhist scholarship seriously. While this monastic education system remains in place today, its impact should perhaps not be exaggerated. McDaniel (2010) has emphasized that the early 20th-century efforts to nationalize, centralize, and formalize monastic education have had limited success in imposing a standardized education on the Thai monkhood.

The boundary between secular and religious education is not impermeable. Indeed, in recent years Buddhist tenets and Buddhist monks have increasingly penetrated the secular education system, as governments have turned to traditional sources of moral authority and instruction in an effort to halt what has been perceived as the degeneration of the country's youth. Since the early 2000 s, the Thai state has 
therefore encouraged public schools to apply Buddhist principles (rongrian withiphut) and to use monks rather than laypersons as teachers of civic morality (Yano 2017). The school curriculum has also been reformed so as to give religiously-based and especially Buddhist ethics a more prominent position, with the option to study secular ethics removed in 2002 (Yano 2010). Conversely, the Thai state has over the past century sought to reform monastic education in order to make it more "useful." As a consequence, secular subjects have come to play a more prominent role within the monastic curriculum, so as to make graduates more able to exercise "secular" leadership in local communities (Ford 2017, 115-116), as well as to make them attractive on the job market once they return to "the world" (Khammai 2007). Also with an eye towards enhancing the secular utility of monastic education, a military-appointed legislature has recently put forward the controversial proposal that monastic examinations in Pali language and Buddhist doctrinal studies should be regarded as equivalent to secular academic qualifications. While the secular and religious education systems remain institutionally separate, the flow of ideas, persons, and resources between them increasingly blurs the boundary.

\section{Political citizenship}

Section 96 of the 2017 constitution of the Kingdom of Thailand prohibits four distinct categories of person from exercising the right to vote. These are the mentally infirm, convicts, those whose political rights have been revoked, and, finally, Buddhist monks, novices, ascetics, and clergy. Similar prohibitions can be found in other laws relating to the exercise of political citizenship, such as election laws and political party laws. Buddhist monks are therefore legally banned from voting in elections, standing as candidates for public office, and establishing or joining political parties. ${ }^{4}$ The exclusion of Buddhist monks from formal political participation is not anti-clerical in intent, but rather motivated by a desire to

\footnotetext{
${ }^{4}$ These legal prohibitions also apply to female renunciants (mae chi).
} 
protect the sangha from being tainted by any association with "dirty" partisan struggles over worldly power (Larsson 2015, 2016a, 2016b).

Religious disenfranchisement provides perhaps the most explicit illustration of the normative position that those who renounce "the world" and enter satsanachak should abandon politics. Further seeking to reinforce this norm are regular reminders from senior sangha ecclesiastics that monks also should not exercise political citizenship in more informal ways, such as by joining "political" protests or in other ways expressing political opinions (Borchert 2016). The Supreme Patriarch has further decreed that Buddhist temple grounds and facilities must not be used for any "political" purposes, such as electioneering (Daily News 2018). However, such ecclesiastic injunctions do not have the force of law, and it is noteworthy that there are no secular legal provisions that prevent temples and monks from participating in electoral campaigns, publicly indicating their support for or opposition to particular parties and candidates, etc. ${ }^{5}$ The enthusiasm with which some monks participate in informal politics serves as a reminder that the ideal of the apolitical bhikkhu is not universally shared within the Thai monkhood.

The impermeability of the boundary that excludes the monkhood from formal political participation is, it must be acknowledged, premised on the boundary between satsanachak and anachak being an extremely permeable one in other ways. Thai men can both enter and exit the monkhood at great ease, with no stigma attached to those who abandon the yellow robe and return to "the world" (at which point political citizenship is restored).

\section{Secularisation without secularism}

5 The Thai case can be contrasted with the United States, which does not ban clergy from voting or running for election, but where the tax authorities regulate the informal political activities of churches (Gorski 2018, 50). 
The main strategy adopted by Thailand's religious and lay elites has been to posit Buddhism as eminently compatible with all relevant demands that modernity has placed upon their state. The approach was pioneered by King Mongkut, who founded and led a Buddhist reform movement that sought to "rationalize" Thai Buddhism by discarding its cosmological and supernatural tenets, so as to make Thai Buddhism compatible with the epistemology of modern empirical science (Thongchai 2010, 2015). Following in Mongkut's footsteps, Thai elites--monarchs or commoners, clergy and laypersons--have tended to assert the compatibility between Thai Buddhism and the modern nation-state, capitalist development, socialism, and democratic politics. Likewise, Buddhism has been presented as a viable basis of religious toleration. In all these respects, the religious and philosophical basis of the Buddhist state has been posited as equal or indeed superior to "Western" political secularism, whether as practiced in Europe and North America, or as attempted in neighbouring Asian countries.

This strategy has been remarkably successful. At the very least Thai history has yet to arrive at an impasse where institutional Buddhism and its fusion with the state is perceived by the country's elites as a major obstacle to progress or to public order. Secularism, as an ideology, has therefore appeared superfluous to many Thai intellectuals. "Proper" Thai Buddhism, it is argued, is modern, universal, and rational, and as such able to deliver what secularism promises, and more thereto.

If anything, critics have charged that Thai Buddhism only too readily has accommodated itself to modernity, especially to the modern state and to the market economy, with claiming that Thai Buddhism has been turned into a prosperity religion (Pattana 2008, Jackson 2017). Some religious conservatives, on the other hand, bemoan what they perceive as the ecclesiastic and political establishment's excessive tolerance towards religious pluralism. Partly in response to proposed "secularizing" reforms of the national education system that were initiated in the late $1990 \mathrm{~s}$, they have mobilized to pressure political elites to more forcefully assert the hegemonic position of Buddhism within the polity (Katewadee 2013). In recent years, therefore, religious pluralism has increasingly come to be viewed less as a point of 
Buddhist pride than as a flaw that threatens to undermine the security of the satsana (Suwanna 2003, Jerryson 2012). Both of these lines of critique have generated political demands for state-led initiatives designed to "strengthen" Thai Buddhism. Even those who advocate for the state to stop meddling in religious affairs recognize that this, ironically, will only be possible through state-led reform of existing laws and institutions.

In Thai intellectual history, proposals for a more radical separation of sangha and state were pioneered by Marxist intellectuals who regarded Thai Buddhism as an opium of the people (Suraphot 2017, 104). In more recent years, a number of Thai intellectuals have begun advocating for secularism from a more liberal ideological position, as they view the state's control over the religious sphere as a serious obstacle for the consolidation of liberal-democratic political institutions (Phiphat 2010, Suraphot 2017, Vichak 2015). The continuing violence in the Malay-Muslim provinces in southern Thailand also casts considerable doubt on the capacity of the Thai-Buddhist state as currently fashioned to foster peaceful relations with religious minorities (Litalien 2013, McCargo 2009).

\section{Conclusion}

The Thai state presents us with a perplexing case. On the one hand, there is clear evidence for the emergence of a distinct "religious" domain and a separate—secular—public sphere of science, economy, and politics, with the boundaries between the two policed by ecclesiastic and lay elites, and occasionally subject to heated political contestation. On the other hand, dominant state ideology rejects any such separation, insisting that that which to the uninitiated might appear as "secular" is subordinated, ultimately, to thamma.

\section{References}


Asad, Talal. 2003. Formations of the Secular: Christianity, Islam, Modernity. Stanford: Stanford University Press.

Baker, Chris, and Pasuk Phongpaichit. 2016. The Palace Law of Ayutthaya and the Thammasat: Law and Kingship in Siam. Ithaca: SEAP Publications, Cornell University.

Borchert, Thomas. 2016. "On Being a Monk and a Citizen in Thailand and China," in in Hiroko Kawanami (ed.), Buddhism and the Political Process. New York: Palgrave Macmillan.

Casanova, José. 1994. Public Religions in the Modern World. Chicago: University of Chicago Press.

Daily News. 2018. “'Phrasangkharat' ok kot ham chat kitchakan kanmeuang nai wat” ['Supreme Patriarch' issues decree banning political activities in temples], 31 August. https://www.dailynews.co.th/politics/663605 (accessed 21 September 2018).

Engel, David M. 1975. Law and Kingship in Thailand During the Reign of King Chulalongkorn. Ann Arbour: Center for South and Southeast Asian Studies, University of Michigan.

Ford, Eugene. 2017. Cold War Monks: Buddhism and America's Secret Strategy in Southeast Asia. New Haven: Yale University Press.

Funahashi, Daena Aki. 2016. "Rule by Good People: Health Governance and the Violence of Moral Authority in Thailand." Cultural Anthropology 31(1): 107-130.

Gorski, Philip S. 2018. “Secularity I: Varieties and Dilemmas,” in Mirjam Künkler, John Madeley, and Shylashri Shankar (eds.), A secular age beyond the west: Religion, law and the state in Asia, the Middle East and North Africa. Cambridge: Cambridge University Press.

Gray, Christine. 1986. "Thailand: the Soteriological State in the 1970s." PhD dissertation. University of Chicago.

Harding, Andrew J. 2008. "The Eclipse of the Astrologers: King Mongkut, His Successors, and the Reformation of Law in Thailand," in Penelope Nicholson and Sarah Biddulph (eds.), Examining Practice, Interrogating Theory: Comparative Legal Studies in Asia. Leiden: Martin Nijhuis Publishers. 
Ishii, Yoneo. 1986. Sangha, State, and Society: Thai Buddhism in History. Honolulu: University of Hawaii Press.

Jackson, Peter A. 2010. "Virtual Divinity: A 21st-Century Discourse of the Royal Influence," in Søren Ivarsson and Lotte Isager (eds.), Saying the Unsayable: Monarchy and Democracy in Thailand. Copenhagen: NIAS Press.

Jackson, Peter A. 2017. "The Supernaturalization of Thai Political Culture: Thailand's Magical Stamps of Approval at the Nexus of Media, Market and State." SOJOURN: Journal of Social Issues in Southeast Asia 31(3): 1-55.

Jerryson, Michael K. 2012. Buddhist Fury: Religion and Violence in Southern Thailand. New York: Oxford University Press.

Jory, Patrick. 2016. Thailand's Theory of Monarchy: The Vessantara Jātaka and the Idea of the Perfect Man. Albany: SUNY Press.

Khammai Dhammasami. 2007. "Idealism and Pragmatism: A Dilemma in the Current Monastic Education Systems of Burma and Thailand," in Ian Harris (ed.), Buddhism, Power and Political Order. London: Routledge.

Kataoka, Tatsuki. 2012. "Religion as Non-religion: The Place of Chinese Temples in Phuket, Southern Thailand." Southeast Asian Studies 1(3): 461-485.

Katewadee Kulabkaew. 2013. "In Defense of Buddhism: Thai Sangha's Social Movement in the Twentyfirst Century." PhD Dissertation. Waseda University.

Keyes, Charles F. 1989. "Buddhist Politics and Their Revolutionary Origins in Thailand." International Political Science Review 10(2): 121-42.

Künkler, Mirjam and Shylashri Shankar. 2018. "Introduction,” in Mirjam Künkler, John Madeley, and Shylashri Shankar (eds.), A Secular Age Beyond the West: Religion, Law and the State in Asia, the Middle East and North Africa. Cambridge: Cambridge University Press.

Larsson, Tomas. 2015. "Monkish Politics in Southeast Asia: Religious Disenfranchisement in Comparative and Theoretical Perspective.” Modern Asian Studies 49 (1): 40-82. 
Larsson, Tomas. 2016a. "Buddha or the Ballot: The Buddhist Exception to Universal Suffrage," in Hiroko Kawanami (ed.), Buddhism and the Political Process. New York: Palgrave Macmillan.

Larsson, Tomas. 2016b. “Keeping Monks in Their Place?” Asian Journal of Law and Society 3 (1): 1728.

Larsson, Tomas. 2018a. "Buddhist Bureaucracy and Religious Freedom in Thailand." Journal of Law and Religion, OnlineFirst, 13 September. https://doi.org/10.1017/jlr.2018.27

Larsson, Tomas. 2018b. “The Political Economy of State Patronage of Religion: Evidence from Thailand.” International Political Science Review, OnlineFirst, 20 June. https://doi.org/10.1177/0192512118770178

Laliberté, André. 2013. “Something Got Lost in Translation: From 'Secularism’ to 'Separation Between Politics and Religion' in Taiwan,” in Bruce J Berman, Rajeev Bhargava, and André Laliberté (eds.), Secular States and Religious Diversity. Vancouver: UBC Press.

Litalien, Manuel. 2013. "The Changing State Monopoly on Religion and Secular Views in Thailand," in Bruce J Berman, Rajeev Bhargava, and André Laliberté (eds.), Secular States and Religious Diversity. Vancouver: UBC Press.

Loos, Tamara. 2006. Subject Siam: Family, Law, and Colonial Modernity in Thailand. Ithaca: Cornell University Press.

Mahmood, Saba. 2015. Religious Difference in a Secular Age: A Minority Report. Princeton: Princeton University Press.

McCargo, Duncan. 2009. “The Politics of Buddhist Identity in Thailand's Deep South: the Demise of Civil Religion?" Journal of Southeast Asian Studies 40(1): 11-32.

McDaniel, Justin Thomas. 2010. Gathering Leaves and Lifting Words: Histories of Buddhist Monastic Education in Laos and Thailand. Seattle: University of Washington Press.

Mérieau, Eugénie. 2018. "Buddhist Constitutionalism: When Rajadhamma Supersedes the Constitution." Asian Journal of Comparative Law. 
National Statistical Office. Statistical Tables. Table 4: Population by religion, sex, and area. http://www.nso.go.th/sites/2014en/Pages/Census/Population\%20and\%20Housing\%20Census/The \%202010\%20Population\%20and\%20Housing\%20Census/Year\%202010/Statistical\%20Tables.pd f (accessed 3 July 2018).

P. A. Payutto (Phrathammapidok). 1994. Rat kap phraphutthasatsana: Thueng wela chamra lang rue yang [State and Buddhism: Is it time for a complete cleansing?] Bangkok: Munithi Phutthatham. Third printing.

Pattana Kitiarsa. 2008. "Buddha Phanit: Thailand's Prosperity Religion and its Commodifying Tactics," in Pattana Kitiarsa (ed.), Religious Commodifications in Asia: Marketing Gods. Abingon: Routledge.

Phiphat Phasuthanchat. 2010. Rat kap satsana: Botkhwam wa duai anachak satsanachak lae seriphap [State and religion: essays on the wordly realm, the religious realm, and freedom]. Bangkok: Siam.

Puli Fuwongcharoen. 2018. “'Long Live Ratthathammanūn!': Constitution Worship in Revolutionary Siam.” Modern Asian Studies 52(2): 609-644.

Reynolds, Frank E, and Mani B Reynolds. 1982. Three Worlds According to King Ruang: a Thai Buddhist Cosmology. Berkeley: Asian Humanities Press/Motilal Banarsidas.

Schedneck, Brooke. 2015. Thailand's International Meditation Centers: Tourism and the Global Commodification of Religious Practices. London: Routledge.

Six, Clemens. 2018. Secularism, Decolonisation, and the Cold War in South and Southeast Asia. Abingdon: Routledge.

Stengs, Christine. 2009. Worshipping the Great Moderniser: King Chulalongkorn, Patron Saint of the Thai Middle Class. Singapore: NUS Press.

Smith, Christian. 2017. Religion: What it Is, How it Works, and Why it Matters. Princeton: Princeton University Press. 
Smith, Donald E. 1974. "Religion and Political Modernization: Comparative Perspectives,” in Donald Eugene Smith (ed.), Religion and Political Modernization. New Haven: Yale University Press. Strate, Shane. 2011. "An Uncivil State of Affairs: Fascism and Anti-Catholicism in Thailand, 19401944.” Journal of Southeast Asian Studies 42(1): 59-87.

Streckfuss, David. 2010. Truth on Trial in Thailand: Defamation, Treason, and Lèse-Majesté. London: Routledge.

Suraphot Thaweesak. 2017. Chak phraphutthasatsana haeng rat su anakhot phutthasatsana thi pen isara chak rat [From state Buddhism to a future Buddhism liberated from the state]. Bangkok: Siam Parithat.

Suwanna Satha-anand. 2003. "Buddhist Pluralism and Religious Tolerance in Democratizing Thailand," in Philip Cam (ed.), Philosophy, Democracy, and Education. Seoul: Korean National Commission for UNESCO.

Thongchai Winichakul. 2010. "Coming to Terms with the West: Intellectual Strategies of Bifurcation and Post-Westernism in Siam," in Rachel Harrison and Peter Jackson (eds.), The Ambiguous Allure of the West: Traces of the Colonial in Thailand. Ithaca: Southeast Asia Program Publications, Cornell University.

Thongchai Winichakul. 2015. "Buddhist Apologetics and a Genealogy of Comparative Religion in Siam." Numen 62 (1): 76-99.

Thongchai Winichakul. 2016. “Thailand's Hyper-royalism: Its Past Successes and Present Predicament."

Trends in Southeast Asia No. 7. Singapore: ISEAS-Yusof Ishak Institute.

Vichak Panich. Rat-tham-nua [State-dharma-confusion]. Bangkok: Matichon, 2015.

von der Mehden, Fred R. 1974. "Secularization of Buddhist Polities: Burma and Thailand," in Donald Eugene Smith (ed.), Religion and Political Modernization. New Haven: Yale University Press. White, Erick. 2003. "The Cultural Politics of the Supernatural in Theravada Buddhist Thailand." Anthropological Forum 13(2): 205-212. 
World Values Survey. Survey Wave 6:2010-2014 - Thailand. http://www.worldvaluessurvey.org/wvs.jsp (accessed 3 July 2018).

Yano, Hidetake. 2011. Buddhism in Public Sphere and Concept of Religion: State-Religion Relationship in Contemporary Thailand.

Yano, Hidetake. 2017. "Religious Activities of Administrative Agencies and the Relation Between Religion and the State in Modern Thailand." Paper presented at APISA, Naresuan University, 2021 October. 